\title{
Tahsin Yücel’in Gökdelen'i bağlamında sinema ve reklam filmlerinde yeni yaşam mimarlarının izinden gitmek
}

\section{Remziye KÖSE ÖZELÇİ ${ }^{1}$}

\begin{abstract}
APA: Köse Özelçi, R. (2020). Tahsin Yücel'in Gökdelen’i bağlamında sinema ve reklam filmlerinde yeni yaşam mimarlarının izinden gitmek. RumeliDE Dil ve Edebiyat Araştırmaları Dergisi, (19), 279-296. DOI: 10.2900o/rumelide.752344.
\end{abstract}

$\ddot{O} \mathbf{z}$

Dilbilim ve göstergebilim alanının en önemli temsilcilerinden biri olmakla birlikte, çok sayıda öykü, roman ve deneme türünde eserler yazan Prof. Dr. Tahsin Yücel'in 2006'da yayımlanan ve 2073 yılını anlattığı "Gökdelen" adlı yapıtı özellikle mekânın insan ve toplum üzerindeki etkisini vurgulaması bağlamında önemlidir. Öte yandan özelleştirilen yargı sistemini ele alan "Gökdelen”, iktidar-medya ve yargı ilişkilerinin kurgusal aktarımı açısından da son derece değerli bir yapıttır. Makalede seçilen reklam ve sinema filminin öykü ve karakterleri, Gökdelen'in temel izleği ve ana karakterlerinin üstlendiği roller bağlamında ele alınmıştır. Bu düşünceden hareketle yapımcılığını Ağaoğlu Şirketler Grubu Başkanı Ali Ağaoğlu'nun inşaat firmasının üstlendiği "AĞAOĞLU MASLAK 1453 İSTANBUL" Projesi reklam filminde ve 2015 yılında gösterime giren "Bana Masal Anlatma" sinema filmindeki müteahhit karakterleri ve bu karakterlerin hedefe yönelik eylemlerinde izledikleri yol ve yöntemleri, her üç anlatı arasındaki "benzer ve farklılıklar" metinlerarası yaklaşımla analiz edilmiştir. Gökdelenin simgesel olarak kullanıldı̆̆ı her üç anlatıda da (roman, reklam, sinema filmi) zaman, mekân ve eyleyenin/karakterin değişmesine karşın, gerçek ve kurgusal dünyada amacın aynı olduğu görülmektedir. Çünkü kendilerini bir “yaşam mimarı” olarak sunan Ali Ağaoğlu da (reklam-konut), uluslararası bir inşaat firmasıyla ortaklaşa yürüttüğü proje kapsamında eski evleri yıkarak yerine gökdelenler dikmeyi hayal eden müteahhit Timur Arslan da (film-konut) romanın ana karakterlerinden Temel Diker gibi tüm gücünü ve enerjisini İstanbul'u "baştan yaratmaya" adamıştır.

Anahtar kelimeler: Tahsin Yücel, Gökdelen, Maslak 1453, Bana Masal Anlatma, yeni yaşam alanları

\section{Following the paths of the new life architectures in cinema and commercials in the context of Tahsin Yücel's Gökdelen}

\begin{abstract}
Prof. Tahsin Yücel, who wrote numerous short stories, novels, and essays, as one of the major representatives in the fields of linguistics, and semiotics, published his "Gökdelen" in 2006 in which he narrated the year of 2073, and which is important in the context of emphasizing the effects of space, especially on individual and society. Dealing with the problem of denationalized judiciary system "Gökdelen" has been exceedingly influential on transferring the relationships between power-media and judiciary fictionally. The stories, and the characters of a commercial, and a movie selected for this article are discussed in the context of the main track, and the roles undertaken by the main characters of "Gökdelen". Based on this idea the constructors, and the target-specific ways,
\end{abstract}

$1 \quad$ Dr. Öğr. Üyesi, İstanbul Gelisim Üniversitesi, İktisadi İdari ve Sosyal Bilimler Fakültesi, Radyo TV Sinema Bölümü (İstanbul, Türkiye), rkoseozelci@hotmail.com, ORCID ID: oooo-ooo1-5965-6176 [Makale kayıt tarihi: 13.02.2020kabul tarihi: 20.06.2020; DOI: 10.29000/rumelide.752344] 
Following the paths of the new life architectures in cinema and commercials in the context of Tahsin Yücel's Gökdelen / R. Köse Özelçi (pp. 279-296)

and methods they apply in the commercial movie of the project of "AĞAOĞLU MASLAK 1453 ISTANBUL”, which is produced by the chairman Ali Ağaoğlu's construction company, belonging to Ağaoğlu Corporate Group; and the movie, "Bana Masal Anlatma", released in 2015 and the "similatities and diferences between these three narratives are analyzed within an intertextual approach. Space, time, and agents/characters are changed in these three narratives (novel, commercial, and movie), in which the skyscraper is engaged symbolically, as in real, and fictional worlds, with the same purposes. For both of the figures; Ali Ağaoğlu, who presents himself as "life architecture" (commercial-dwelling); and the other is constructor Timur Arslan, who dreams demolishing old houses and constructing new skyscrapers in place of them within a project he conducts with an international construction company (movie-dwelling) devoted their all energy, and power to "recreate" Istanbul from the scratch like Temel Diker, one of the main characters of the novel.

Keywords: Tahsin Yücel, Gökdelen Maslak 1453, Bana Masla Anlatma, new life spaces

\section{Giriş}

Ali Püsküllüoğlu Türkçe Sözlüğünde gökdeleni; “yirmi, otuz ya da daha çok sayıda katı bulunan yapı” (2002, s.659) olarak tanımlamaktadır. Kentsel çevre içinde kitlesel etki yaratan ve yüksekliği yapı boyutlarını çok çok aşan yapılar (Begeç, Hamidabad, 2015) olarak, alışılmışın çok üstünde yüksekliklere sahip olduklarından göğü delen anlamında gökdelen (skyscraper) sözcügü̈yle ifade edilen bu yapı modelinin ilk örnekleri, Amerika Birleşik Devletleri'nin New York ve Chicago kentlerinde görülür. 19. yüzyılın sonlarından itibaren özellikle Endüstri Devrimi'yle birlikte ekonomik, toplumsal ve teknolojik alanda yaşanan değişim ve gelişimlerle yüksek yapılı binaların yapımı daha da artar. Önceleri Avrupa kentlerinde (20. yüzyılın ilk dönemlerinde), 20. yüzyılın sonlarına doğru ise Asya'da yüksek yapılı binalar, kentlerin önemli yaşam alanlarından biri olarak mimaride kendine yer bulur. Göğü ve bulutları delen (gökdelen) bu yüksek yapılı binalar, zaman içerisinde "güçlü ve modern kent" algısının/anlayışının göstergesi olur. Öylesine ki günümüzde en yüksek gökdelene sahip olmak, varsıl ve gelişmiş kent imajı için "tek başına” bile önemli bir değer nesnesi olabilmektedir. ${ }^{2}$

Çok katlı yüksek yapılar (gökdelenler), modern ve güçlü kent imgesinin önemli simgelerinden biri kabul edilmekle birlikte3 daha ilk yapıldığı tarihlerden günümüze tartışma ve dava konusu olmuştur.4

2 Bu konuda Prof. Dr. Serdar Sağlam’ın “Üniversite Öğrencilerinin Çok Katlı Bina ve Gökdelenler Hakkındaki Düşünceleri” başlıklı makalesinde, gelişmişliğin göstergesi ve çağdaş bir sembol olarak çok katlı binalar ve gökdelenler konusunda düşünceleri sorulan öğrencilerin yanıtları bu açıdan önemlidir:

"Bir s,ehrin ve ülkenin gelis,miş,iğinin, güc,lü sanayinin, ekonominin ve ihtis,amın en önemli göstergelerinden biri c,ok katlı bina ve gökdelenlerdir. Mesela New York dünyanın en zengin ve güzel s, ehirlerinden biridir”.

- "C,ok katlı binalar ve gökdelenler moderndir, görsel ve estetik ac,ıdan mükemmellerdir. Büro ve isyerlerinde de daha gelis, mis, bir teknoloji kullanılmakta ve konforlu bir c,alıs,ma ortamı sunulmaktadır”. Bkz. Sağlam, S. (2018). “Üniversite Öğrencilerinin Çok Katlı Bina ve Gökdelenler Hakkındaki Düşünceleri”, Üçüncü Sektör Sosyal Ekonomi, 2018, 53 (3), s.1323-1336, doi. 10.15659/3-sektor-ekonomi.18.12.1053.

3 Söz konusu görüşün herkesçe kabul görmediği de ayrıca göz önünde bulundurulmalıdır, ancak makalenin sınırlılıkları çerçevesinde bu konuya yer verilmemiştir.

Tarihte "yüksekliği”" dolayısıyla Tanrı tarafından halkının cezalandırıldığı Babil Kulesi bu açıdan örnek verilebilir. Mezopotamya'daki geleneksel mabed kuleleri olan zigguratların (Akkadca zakaru "dikmek, yükselmek"ten) en büyüğü olan ve baştanrı Marduk için Kral Nemrud tarafından yaptırılan Babil Kulesi’nin kaynaklara göre 91x91 m. ölçülerinde bir kare taban üzerine oturduğu, tamamının $75 \mathrm{~m}$. yükseklikte gittikçe küçülen altı kattan meydana geldiği ve tepesinde kat sayısını yediye, toplam yüksekliği 91 metreye çıkaran mavi sırtlı tuğlalardan oluştuğu aktarılmaktadır. Tevrat’a göre tufandan sonra Sinear bölgesine yerleşen Hz. Nuh'un oğulları, "Bütün yeryüzü üzerinde dağılmayalım diye gelin kendimize bir şehir ve başı göklere erişecek bir kule bina edelim...” derler ve inşaata başlarlar. Ne var ki Tanrı, hepsinin bir kavim olduklarının görünce anlaşamasınlar diye dillerini karıştırır ve onları bütün dünyaya dağıtır; inşaatı yarım kalan şehre de dillerinin orada birbirine karışmasından dolayı Babil denilir. (Tekvin, 11/1-9) Bu efsanede gerçek payı

Adres

Kırklareli Üniversitesi, Fen Edebiyat Fakültesi, Türk Dili ve Edebivatı Bölümü, Kayalı Kampüsü-Kırklareli/TÜRKIYE e-posta: editor@rumelide.com
Adress

Kırklareli University, Faculty of Arts and Sciences, Department of Turkish Language and Literature, Kayalı Campus-Kırklareli/TURKEY e-mail: editor@rumelide.com 
Tartışılma nedenlerinden en önemlisi, binaların yükseklik sınırlamaları üzerinedir. İlk yükseklik sınırlaması 1893 yılında Chicago'da (ABD) yapılan binalar içindir. Sonrasında 1915 yılında yüksekliği nedeniyle çevresindeki yapıların ışık ve hava almasını engellediği gerekçesiyle New York’ta yapılan 40 katlı 164 metrelik Equitable Building için takip eder (Sağlam, 2018, s.1323-1336). 19. yüzyılın sonlarından (ilk yapıldıkları tarihlerden) günümüze kadar binaların yükseklik sınırlamaları sorunu sadece ABD'de değil, diğer ülkelerde ve ülkemizde de hep tartışma ve dava konusu olmaya devam etmektedir. Gerek bireysel gerek örgütsel olarak yürütülen tüm mücadelelere rağmen (yüksek katlı binaların ekosistemi bozması, doğayı tahrip etmesi, sınıfsal ayrışmaları arttırması, tarihi dokuyu yok etmesi...gibi nedenlerle) özellikle kentsel dönüşüm sonrası yapılarla gökdelenlerin sayısının ve yükseklik sınırlamalarının giderek arttığı da yadsınamaz.

Dilbilim ve göstergebilim alanında çok değerli yapıtlar vermesinin yanı sıra, yazdığı roman, öykü ve denemeleriyle tanınan Prof. Dr. Tahsin Yücel'in “Gökdelen” adlı yapıtı, makalenin temel çıkış kaynağıdır. Çok yönlü okumaya açık olan yapıt, İstanbul'u, yüksek yapılı binaların ilk çıkış yeri olan, gökdelenleriyle ünlü New York kentine dönüştürmek isteyen (hatta New York'takilerden daha iyi ve daha -en yüksek- binalar yapmak hayaliyle) roman karakteri müteahhit Temel Diker özelinde metinlerarası yaklaşımla; ülkemizde inşaat sektöründe adını sıkça duyduğumuz iş insanı Ağaoğlu Şirketler Grubu Başkanı Ali Ağaoğlu'nun inşaat firmasının üstlendiği "AĞAOĞLU MASLAK 1453 İSTANBUL” Projesi reklam filmi (Oflu Trump Ali Ağaoğlu) ve 2015 yllında gösterime giren "Bana Masal Anlatma" sinema filmi (müteahhit karakter Timur Arslan) ve bu karakterlerin hedefe yönelik eylemlerinde izledikleri yol ve yöntemleri, her üç anlatı arasındaki "benzer ve farklılıklar" bağlamında analiz edilmiştir.

G. Genette, "bir yapıtla ondan öncekiler ve sonrakiler arasında kurulan ilişkilerin okur tarafından algılanmasına, metinlerarası ilişkiler" 5 adını verir (Kıran ve Kıran, 2011, s. 359). Makalede ise amaçlanan Genette'in tanımladığı biçimiyle bu görüşünü; ilk ve önceki metnin Tahsin Yücel’in “Gökdelen” (2006 yllında yazılan) yapıtının ele alındığı ana metin ile, gönderge metinlerinin farklı anlatı türlerinden seçildiği reklam filmi (2012 yllında gösterime giren Maslak 1453 İstanbul) ve sinema filminde (2015 yllında gösterime giren Bana Masal Anlatma) yer alan "müteahhit karakterleri” ve bu karakterlerin "olay örgüleri/eylem alanları" konu düzeyinde kurulan ilişki yansılaması (parodi) olarak tanımlamaktır (Aktulum, 2018, s. 76).

Gökdelenin (yüksek katlı binalar) simgesel olarak kullanıldı̆̆ı her üç anlatıya, kurulan ilişkilerin yansılamasını daha iyi irdeleyebilmek için sırasıyla (önceki metin; sonraki metin I; sonraki metin II) yer verilmektedir. Bu bağlamda Tahsin Yücel’in “Gökdelen”i ve müteahhit karakteri Temel Diker’i İstanbul’u ikinci bir New York’a dönüştürme ülküsünde yardımcı olan ana karakter ve olay örgüsünün ilişkiler ağı içerisinde anlatarak başlayalım.

olduğu ve başı göklere yükselen kulesiyle Allah’a isyanı sembolize etmesidir. Bkz.Sargon, E. Babil, Eski Mezopotamya'nın en büyük ve en ünlü şehri, https://islamansiklopedisi.org.tr/babil (erişim tarihi: 17.03.2020)

5 Bu terimi ilk kez 1966 yllında M. Bakhtine'nin çalışmalarından esinlenen J. Kristeva kullanmış ve şöyle tanımlamıştır: "Her metin bir alıntılar mozaiği olarak okunur, her metin bir başka metne dönüşür, bir başka metni içine alır. Metinlerarası ilişkiler kavramı öznelliklerarası ilişkiler kavramının yerini alır.” Bkz: Kıran, A., Kıran, Z. (2011). Yazınsal Okuma Süreçleri. Ankara: Seçkin Yay. s.359; Stam, R. Vd. (2019). Sinemasal Göstergebilim Sözlügü. Çev: Simten Gündeş. İstanbul: Es Yay. s.254-264. 
Following the paths of the new life architectures in cinema and commercials in the context of Tahsin Yücel's Gökdelen / R. Köse Özelçi (pp. 279-296)

\section{1.Önceki metin: Gökdelen}

İlk basımı 2006 yılında yapılan ve yargının özelleştirilmesi ana ekseninde kurgulanan Tahsin Yücel'in "Gökdelen" adlı romanını, özellikle öykünün anlatıldığı sürem ve geleceğe ilişkin öngörüler açısından değerlendirdiğimizde, George Orwell’in ünlü eseri $1984^{6}$ gibi distopik bir yapıt olarak okuyabiliriz.

Romanın ana karakterlerinden avukat Can Tezcan'ın karabasanıyla başlayan yapıt, 2073 yılının İstanbul'unda gerçekleşmektedir. 2073 aynı zamanda Türkiye Cumhuriyeti’nin kuruluş yılı olan 1923 dikkate alındığında Cumhuriyet'in 150. yılına karşılık gelmektedir. 2073'te ülke sınırları içerisinde sahillerin bile özelleştirilip satıldığı bir ortam ve süreç egemendir. Nitekim romanda bu durum çeşitli sayfalarda vurgulanır:

"Hem de biliyorsun, başımızdaki herifler bunca yıldır bu ulusun nesi varsa hepsini özelleştirdiler, maden, orman, ırmak, liman, fabrika, hastane, üniversite, ilkokul her şeyi, her şeyi sattılar haraç mezat...” (Yücel, 2006, s. 44).

Öğrenciliği sırasında aktif bir Marksist olan Can Tezcan, İstanbul'u yaptığı gökdelenlerle ikinci bir New York'a dönüştürme hayaliyle yaşayan, bu nedenle Niv Yorklu lâkabıyla tanman zengin müssterisi Temel Diker'in yasal sorunlarını çözümlemek için, yargının özelleştirilmesi tasarısını ortaya atar. Çünkü İstanbul'un her yerine gökdelenler diken Temel Diker'in en büyük projesi, annesi Nokta Hanım'ı çağrıştıran, New York’takinin üç katı büyüklüğündeki “özgürlük anıtı"nın benzerini Sarayburnu'na yapmaktır. Anıtı en iyi görebileceği yer olan Cihangir'deki bir araziye kendisinin de yaşayacağı büyük bir gökdelen dikmek ister. Ancak projeleri sürekli yargı engeline takılır. Anıta engel Topkapı Sarayı'dır, Cihangir'deki gökdelene de arazide yer alan müstakil evin sahibi emekli bir öğretmendir. On altı gökdeleniyle Manhattan'a benzettiği Cihangir'de, gökdelenlerin düz sıralar oluşturmasını engelleyen yüz beş metrekarelik bahçeli evin sahibi emekli öğretmen Hikmet Şirin, kendisine önerilen baş döndürücü rakamlara rağmen evden çıkmamıştır. Bu durum ise müvekkili Temel Diker'i fazlasıyla hırçınlaştırmıştır. Oysa "son yıllarda, 'nice temel yasanın hoyratça çiğnenmesinden sonra, hukukun hukuk olmaktan çıkmak üzere gelip dayandığı son sınırdı belki bu ev', uzmanların aşıldı mı 'ortada hukuk diye bir şey kalmayacağını' düşündükleri son noktaydı” (Yücel, 2006, s. 41). İşte tam da bu noktada romanın ana izleği olarak öne çıkarılan yargının özelleştirilmesi tasarısı, her şeyin özelleştirildiği bir ortamda -düzenin tutarlılı̆̆ı- açısından da gereklidir. Nitekim Can Tezcan davaya "devletin hâlâ yargıyı kendi tekelinde tutmasının aykırılığından" yola çıkarak devam edecektir.

Can Tezcan, yargının özelleştirilmesi tasarısının yaşama geçirilme noktasında, en önemli güç dayanaklarının medya ve iktidar seçkinlerinin desteği olduğunu çok iyi bilmektedir. Ona göre bu işten çıarı olmayan yoktur. Bu aşamada medya-iktidar ilişkilerine kısaca değinmekte yarar vardır.

\subsection{Medya-iktidar ilişkileri bağlamında "Gökdelen"}

“Benim tek derdim bu kenti yeniden kurmak" /Temel Diker

6 1984/Bin Dokuz Yüz Seksen Dört, İngiliz yazar George Orwell’ın 1947-1948 yıllarında yazdığı ve ilk kez 1949 yılında yayınlanan yapitıdır. Orwell bu yapıtında, “1984” yılını yani gelecekle ile ilgili düşüncelerini roman kahramanı Winston Smith’in üzerinden yansıtır. Tahsin Yücel de 2006 yllında yayınlanan yapıtında geleceği yani 2073 yllını öngörür. Gökdelen yapıtının bir distopya edebiyatı ürünü olduğuna ilişkin ayrıca bkz. Demir, R. (2019), Bir Kent Distopyası Olarak Tahsin Yücel'in Gökdelen'i ve Romanın Distopya Edebiyatı İçindeki Yeri, Çukurova Üniversitesi Türkoloji Araştırmaları Dergisi (ÇÜTAD), 4 (2), s. 446-467. 
Günümüzde medya seçkinlerinin, bireylerin tutum, davranış ve tercihlerinde ciddi boyutlarda etkili olduğu yadsınamaz bir gerçekliktir. Bu bağlamda dördüncü kuvvet olarak adlandırılan medya, kimi zaman destek" olduğu siyasi parti ya da güç odaklarının basın-yayın organı gibi çalışırlar; kimi zaman da destekledikleri parti/güç odaklarının rakiplerine yönelik aleyhte yayınlar yaparak hizmet verebilirler. Bir anlamda aralarında "karşılıklılık" esasına dayalı bir ilişki durumu söz konusudur. Nitekim Gökdelen'de avukat Can Tezcan, yargının özelleştirilmesi konusunda "karşllıklılık" esasına dayalı olarak kamuoyu oluşturması için, yakın arkadaşı Cüneyt Ender'le iletişime geçecektir. Cüneyt Ender, ülkenin en büyük gazetelerinden birinin başköşe yazarıdır. Bol resimli ve bol yarı çıplak kadınlı bir halk gazetesi olmakla birlikte, bir yandan medya patronunun servet ve ilişkileri sayesinde, öte yandan kimi köşe yazarlarının yetenekleri sayesinde en saçma ve gerçekdışı haberleri güncelleştirip kamuoyuna mal etmekte, gündemi saptırarak iktidar seçkinlerine yardım etmekte önemli bir işlev üstlenmekteydi. Bourdieu'nun söylemiyle bir tür iç -tanışıklık dünyası egemendir televizyonda. Sürekli çağrılanların oluşturdukları evren, sürekli bir öz-güçlendirme mantığı içinde işleyen kapalı bir içtanışıklık dünyasıdır. Bunlar birbirine karşı olan insanlardır, ama bu karşıtlık öylesine uzalaşımsaldır ki... Bunlar sağınızı solunuzu şaşırtan insanlardır. Acaba izleyici bu suç ortaklığının bilincinde midir? (Bourdieu, 1997, s. 63) Gökdelen'de izleyici bu uzlaşımsal suç ortaklığının farkında mıdır bilinmez, ancak ekranda muhalif, gündelik yaşamda/ekran dışında yakın arkadaş olan bu ikilinin katılımıyla çok sayıda televizyon yayınları gerçekleşir, röportajlar yapılır.

\begin{abstract}
"Ne olursa olsun, tüm bu tartışmalara öncelikle iki kişi yön vermekteydi: Can Tezcan ve Cüneyt Ender. İkisinin de her gün en az birkaç gazetede yeni bir fotoğrafını ve yeni bir demecini görmek, her hafta üç dört kez yan yana ya da karşı karşıya oturup televizyonda yargının özelleştirilmesini savunmalarını izlemek alışılmış bir şeydi artık. Kolaylıkla kestirilebileceği ve eldeki belgelerin de gösterdiği gibi üç aşağı beş yukarı aynı şeyi yineliyorlardı hep, konuşma düzenleri bile aynıydı; sunucu ilk sözü tartışmanın başlatıcısı Cüneyt Ender'e veriyor, Cüneyt Ender yürürlükteki yargı düzeninin ana çizgilerini açıklıyor, sonra sorunun hukuksal temellerine ve içerdiği devrimsel yeniliklere gelince de parmağıyla da Can Tezcan'ı göstererek "işte hukuk burada” diyordu." (Yücel, 2006, s.90)
\end{abstract}

Katıldıkları programlarda ve gazetelere verdikleri röportajlarda aynı yöntem ve söylemleri kullanarak, kamuoyunu yargının özelleştirilmesinin haklılığını benimsetmeye ve kabullenmeye razı ederler. Çünkü her ikisi de medyanın "toplumsal rızanın kazanıldığı ya da kaybedildiği önemli bir mücadele alanı olduğunu gayet iyi bilmektedir. Van Dijk 'Söylemin ve İktidarın Yapıları' adlı makalesinde; birçok iktidar sahibinin (ve konuşmalarının) haber medyasında yeknesak bir şekilde yer aldığını ve böylece iktidarlarının daha da onaylanabileceğini ve meşrulaştırılabileceğini vurgular. Seçmeci kaynak kullanımı, tekdüze haber temposu ve haber başlıklarının seçimi yoluyla haber medyası hangi haber aktörlerinin kamuya yeniden sunulacağına, onlar hakkında neler söyleneceğine karar verir." (İnceoğlu, 2006)

Yargının özelleştirilmesi sürecinden herkesin çıkarı söz konusudur. Herkes bir anda tek ses, tek vücut oluvermiştir. Can Tezcan adalet dağıtıp, haksız bir şekilde mahkûm olan arkadaşı Varol Korkmaz’ı kurtaracak, gazeteci Cüneyt Ender yargının özelleştirmesini destekleyen yazıları sayesinde göğü delen gökdelenlerden birinde bir daireye sahip olacak, gökdelenlerin mimarı Temel Diker her yere diktiği gökdelenleriyle İstanbul'u Newyork'a çevirecekti. Elbette iktidar seçkinleri ise yargıyı satarak başlangıçta bir gökdelende daire, yüz elli bin dolar ve kendi geleceklerini maddi manevi koruyacak garantilere sahip olacaklardı. Böylece, "medyayı elinde bulunduranlar açısından hangi politikacının ne olduğundan çok, kendi kâr ve çıkarları önemli görülebilmektedir. Medya çoğu zaman halk adına iktidarın denetlenmesi görevinden çok, medyayı elinde tutanların kâr ve çlkarları doğrultusunda iktidarı belirlemenin aracı konumuna gelmektedir.” (Avşar, Demir, 2005, s.325). Bu bağlamda ülkede 
Following the paths of the new life architectures in cinema and commercials in the context of Tahsin Yücel's Gökdelen / R. Köse Özelçi (pp. 279-296)

ciddi bir kampanya başlatılır. Tecimsel ve siyasal etmenin de eklendiği haber basını kanaat basınına dönüşür. Bücher, böylesi bir gelişmeyi; “Gazeteler salt haber yayımlayan müesseseler olmaktan çıkıp kamuoyunun taşıyıcıları ve yönlendiricileri, parti politikasının mücadele araçları oldular. Gazete işletmesinin iç örgütlenmesi bakımından bunun sonucu, haber toplama ile haber yayımı arasına yeni bir eklemin girmesiydi: Yazı işleri (redaksiyon) gazete yayımcısı açısındansa bu gelişmenin anlamı, yeni haberler satan birisi iken, artık kamuoyu taciri olmasiydı." (Habermas, 2014, s.306) Romanın çeşitli bölümlerinde, yargının özelleştirilmesi ve bu doğrultuda bir kamuoyu beklentisi/baskısı oluşturulması konusunda medya çalışanlarının oynadığı etkin rol ve iktidar-medya ilişkileri vurgulanir.

“... Örneğin çok ünlü bir bayan yazarımız müzelerden ormanlara her şeyin çoktan "halka” satılmış olduğu bir ülkede yargının da satışa çıkarılmasının hiç kimseyi şaşırtmaması gerektiğini söylerken, en az onun kadar ünlü bir erkek yazarımız ülkelerin devlet elinde bulunan her şeyi özelleştirerek kalkındıkları bir dönemde yargının özelleştirilmesinde fazlasıyla geç kalındığını savunuyor, bir başkası yargının özelleștirilmesini gönülden onaylarken, yabancı bir kuruluşa satılmasında "sayısız yararlar" bulunduğunu ve bu ülkede hukukun egemenliğinin ancak böyle sağlanabileceğini vurguluyordu." (Yücel, 2006, s. 86)

Louis Althusser'e göre medya, devletin en önemli ideolojik aygıtlarından bir tanesidir. Devlet ve iktidar seçkinleri, kendilerini var edebilmek için çeşitli araçlara gereksinim duyarlar. Althusser, Antonio "Gramsci'nin rıza ve baskı arasındaki” ilişkileri üzerine kurguladığı bu araçları, "devletin ideolojik aygıtları ve devletin baskı aygıtları olarak ikiye" ayırır. Ordu, emniyet güçleri, mahkemeler devletin baskı aygıtlarını oluştururken (DBA); eğitim, aile, medya, kilise (dini kurum ve örgütler) ve siyasi partiler ise devletin ideolojik aygıtlarıdır (DİA). Adından anlaşılacağı üzere baskı aygıtları devletin tehditkâr yönünü oluşturan merkezi bir yapılanma iken, sivil toplum kurumlarını anımsatan ideolojik aygıtlar görece biraz daha bağımsızdır ve farklı işleyiş biçimlerine sahiptirler. "Eğitsel kurumlar egemen ideoloji için en kullanışlı develetin ideolojik aygıtlarıdır. Aile, okul, medya hepsi dilsel veya dil dışı pratikler yoluyla örgün ya da yaygın eğitim vererek özneyi yeniden üretmeye ya da iktidarın istediği yönde biçimlendirmeye ve Marcuse'un deyimiyle "tek boyutlu insan"lar haline getirmeye çalışır” (Çoban, 2006, s. 89-116).

Devletin baskı aygıtları (Can Tezcan yönetimde mahkemeler) ile devletin ideolojik aygıtları (Başbakan ve Adalet Bakanı yönetimde siyasi partiler; Cüneyt Ender yönetiminde medya) arasında yürütülen işbirliği sonunda kamuoyunda neredeyse tek bir düşünce egemen olur. Böylece temel ilkelerden yola çıkarak hazırlanan otuz beş sayfalık yasa tasarısı hazırlanır ve 16 Mayıs 2073'te hükümet tasarısı olarak Türkiye Büyük Millet Meclisi’ne sunulur. 24 Mayıs 2073’te, kimi muhalefet milletvekillerinin de iktidar milletvekillerine katılmasıyla \%76 oy çokluğuyla yasalaşır, 26 Mayıs 2073’te de cumhurbaşkanınca onaylanarak, 27 Mayıs 2073’te Resmi Gazete'de yayımlanarak yürürlüğe girer.

Az satışlı iki İstanbul gazetesi dışında, medya çalışanlarının ve yöneticilerinin neredeyse tek ses olduğu bu süreçte muhalif olan gazeteciler ise sistemin dışına atılırlar.

Veysel Çakır Resimli Gündem'deki köşesinde sık sık değiniyordu bu gidişe, her seferinde de dalgasını geçiyor, Niyorklu'nun gökdelenlerinin ülkeye olmasa da kente eşitliği getirdiğini ve eski düzenin tüm kalıntılarını, mahalleyi, komşuluğu ortadan kaldırmaya, bu arada, böyle bir ortamda, yoksullara yer olamayacağına göre, yoksulluğa son verildiğini söyledikten sonra, İstanbul'un beş yüz elli metrelik gökdelenleriyle dünyamızın Tanrı'ya en yakın kenti olduğunu kesinliyordu.Ama 17 Eylül 2073'te yayımlanan "Büyük Utku” başlıklı yazısını bu düzeye ancak yirmi birinci yüzyılın son çeyreğine doğru ulaşabilmiş olmamıza bakılırsa, insanlık gerçekten çok yavaş geriliyor” diye noktalayınca, köşesi bir daha açılmamasıya kapatıldı ve kapatanların edimini ödüllendirmek için olacak, Çakır'ın yazılarından boşalan yerde sürekli olarak gökdelen tanıtımları yayımlanır oldu.(Yücel, 2006, s.247) 
Sisteme karşı çıktığı ve yargının özelleştirilmesi sonucunda yaşanılacak olumsuzluklar hakkında haber yaptığı için, çalıştığı gazeteden atılan Veysel Çakır’ın karşılaştığı durum ise, basın çalışanlarının en ciddi ve en büyük sorunlarındandır. "Amerikan Senatör'lerinden Joseph McCarthy bir haberi doğrudan yalın haliyle tarafsız bir şekilde yazan muhabiri 'deli gömleği giymiş muhabir' olarak nitelemektedir." (Şimşek, 2009, s.124-143) Cüneyt Ender gibi kendi çıkarları için siyasilerin beklentilerine uygun haber yapan gazeteciler ve medya patronlarına karşılık, işinden ve köşesinden olma pahasına işini dürüstçe yapan Veysel Çakır gibi “deli gömleği giymiş gazetecilerin” varlığını daha da önemli kllıyor.

\subsection{Yılkı Adamları ya da Kentsel Dönüşümün Attıkları}

İstanbul'u dünyada eşi benzeri olmayan yükseklikteki binalarla yeniden kurma ülküsüyle, her şeyi göze alan ve bu erekle avukatı Can Tezcan'ın yargı ve medya aracılığıyla hedefe en kısa zamanda ulaşması için, her yolu denemesi konusunda baskı kuran Temel Diker, despotça tutum ve davranışlar sergilemekten de sakınmaz. Çünkü kendisine göre yaptı̆̆ı idealize olandır. Bunun için her firsatta; "Ben yeni bir kent kuruyorum," der Temel Diker; "Hepsi aynı biçimde, aynı yükseklikte gökdelenlerden oluşan bir kent... Gökdelenlerin tek farkı numaraları olacak, bir de renkleri. ... her yer tıpkısının aynı, her yer eşit ... Böylesi Amerika'da bile yok... İstanbul, New York'u geçecek, böylece çağının kenti olacak.” Bu bağlamda birbiriyle aynı yükseklikte bulunan gökdelenler, tektipleşmenin/standartlaşmanın, kimliksizleşmenin/ruhsuzlaşmanın ve gelenekle olan bağların kopuş,unun/metalaştırmanın bir göstergesi olarak karşımıza çıkmaktadır. Kürşat Bumin, "Demokrasi Arayışında Kent" adlı yapıtında despotların kendilerini mimar olarak gördüklerini, toplumun mimarı olarak, insanları da uygun yapılardaki kentlerde istedikleri gibi biçimlendirdiklerini ifade eder. $\mathrm{Bu}$ anlayış ise mimari çalışmalarla şehirciliğin politika ve ideoloji bağlamında iç içe olduğunun göstergesidir. Gökdelenlerin mimarı Temel Diker bir yandan her istediği yere gökdelenlerini dikip, İstanbul'u Newyork'a çevirirken, öte yandan İstanbul'un altını üstüne getirerek, tas, üstünde tas, bırakmayarak, önüne çıkan her şeyi yıktırmıştır. Kent, çevresinde kendinden de yüksek moloz dağlarının olduğu, bir tür açıhhava çöplüğüne dönüşmüştür. Öylesine ki gökdelenleri için tarihi ve geleceği yok etme pahasına Ayasofya’yı, Topkapı'yı, Süleymaniye'yi de yıkacaktır. Bu bir anlamda kendisine ve çevresine "yabancılaşarak yalnızlaşan" insanların giderek çoğalmasıdır. Çünkü "Yabancılașma, duyguların akışkanlığının kaybedildiği bir ortamda uzamsal olarak da kalıpların hâkimiyet sürdüğü keskin çizgili yapılarla artar ki bunun temsilcisi gökdelenlerdir. Betonların göğe doğru yığıldı̆̆g bir alanda evrensel uyum da zedelenmis, olur. Yeryüzüyle bağlarını koparan insan kendinden de kopmuștur" (Küçük Karaca, 2015, s.1445-1466). Romanın çeşitli bölümlerinde İstanbul'un o güne dek yapılmıs, en yüksek yüz elli üc, gökdeleninden birinin sondan üc, önceki katında, yani s,öyle böyle bes, yüz otuz bes, metre yukarısında oturan Tezcan Ailesi'nin betimlendiği bölümlerde "yabancıllaşma”, "yalnızlık” ve kent insanından "soyutlanmışlık” duygusu kendini hissettirir. Özellikle gökdelenlerden, mekikleriyle evlerine giden ve bu nedenle yeryüzünden ve aşağıda yaşayan insanlardan uzak kalan bireyler giderek yaşadıkları göğe yükselen yapılarda esaret altına alınarak yabancılassma duyguları artmaktadır.

“...Tüm kenterler gökdelenlere “yerleșiyor, yerleștikleri katların yüksekliği oranında as,ağıları ve as,ağıdakileri küçük görüyor, yollarda oraya buraya seğirten insanları birer karınca olarak niteleyecekleri geliyordu; ancak, günler gecțikç, așağılara indikleri ve dünyaya herkesle aynı düzeyden baktıkları zamanlarda da benzerlerini gene karınca gibi görmeye başlıyor... kendileri de küçülmüs, birer karıncaya dönüssmüs, gibi bir duyguya kapılıyor, bir an önce yukarılara, gökdelenlerine dönmek istiyorlardı.” (Yücel, 2006, s.246) 
Following the paths of the new life architectures in cinema and commercials in the context of Tahsin Yücel's Gökdelen / R. Köse Özelçi (pp. 279-296)

Temel Diker’e göre eski ve tarihi evlerin yıkılıp yerine gökdelenlerin yapılması, insanların en doğal yaşam haklarıdır. Çünkü “yeryüzünde pislikten, mikroptan, virüsten geçilmez oldu, bunlar çoğaldıkça nice kuşların, nice böceklerin, nice bitkilerin soyu hızla tükeniyor, insan sayısı da hızla azalmakta. Öyleyse çözüm yeryüzü düzeyinden elden geldiğince uzaklaşıp gökdelenlerin temiz ortamında yaşamak gerek." (Yücel, 2006, s.43) Yeryüzünü temizleme işlemleri yalnızca gökdelenleri dikmekle kalmayacak, zenginliğin ve gücün göstergesi olan gökdelenlerde yaşayamayacak düzeyde olanların da olabildiğince kentin dışına atılmasıyla gerçekleştirilecektir. Bir anlamda zengin ve güçlülerin dışında kalan yoksul ve güçsüzlerin kentin kurmaca görüntüsüne zarar vermemek için uzaklaştırılmaları gerekecektir. Tıpkı romanda yer alan, ișe yaramadığı vakit doğaya atılan yılkı atları gibi. 2073'te ise yılkı atlarının yerini yılkı adamları almıştır. Romanda yılkı adamlarının varlığına ilk kez Can Tezcan'ın üniversiteden arkadaşı Rıza Koc'’la konuşma anında tanıklık ederiz. Rıza Koç, arkadaşının aksine hala komünizmin savunuculuğunu yapan ve bu doğrultuda kitaplar yazan bir karakterdir. Rıza Koç yılkı adamlarının varlıklarından habersiz olan arkadaşına onları șu ş̦ekilde anlatır:

\begin{abstract}
"Bunda anlaşılmayacak bir șey yok, dostum. Siz meyveyi, sebzeyi, hatta ekmeklik buğdayı bile seralarda yetiştirirken, ta Misır'dan kalkıp gelen leylekleri makineli tüfeklerle vurdurturken, insanlarımızın büyük çoğunluğu dağda, bayırda aç, çıplak dolaşmaya, ağaç kabuğu, ot, solucan, çekirge, kurbağa, kaplumbağa, yenilebilecek ne bulursa yiyerek, içilebilecek ne bulursa içerek oradan oraya sürüklenip duruyor... "Bana bak, sen bugüne dek yllkı adamları diye birşey işitmedin mi yoksa?" diye gürledi. "Bu kadar mı daldın o gülünç özelleştirme masalına? Biliyorum, basınımızda bu konudan söz etmek de yasak. Gene de senin gibi bir komünist eskisinin, kısa bir süre için de olsa, geniş kitlelerin yaşamına ilgi duymuş bir uyanık adamın bunu işitmiş olması gerekir. Hiç işitmedin mi gerçekten? Can Tezcan dostuna şaşkınlıkla bakıyor, kendisini işletip işletmediğine karar veremiyordu. Gül, gelsene bir dakika! diye seslendi. Şu adam neler anlatıyor: Türkiye'de yılkı atları gibi yılkı adamları varmış, tıpkı tarihöncesindeki insanlar gibi derede tepede, aç, çıplak dolaşarak ot, solucan, kurbağa, çekirge, ne bulursa yiyen yılkı adamları, 2073 yllında" (Yücel, 2006, s.110-111).
\end{abstract}

Mekiklerle her yere gittikleri için yılkı adamları gökdelenlerden görülememektedirler. Bu nedenle "yılkı adamları" Can ve Gül Tezcan'a inandırıcı gelmez. Bu durum bize on sekizinci ve on dokuzuncu yüzyılın bazı Avrupa kentlerini anımsatmaktadır. "Manchester'de olduğu gibi, iş̧̧i mahalleleri o derece "iyi” yerleştirilmişti ki, varlıklı birisi bir işçi mahallesi ya da işçilerle karşılaşmadan yıllarca yaşayabilirdi. Burjuvalar, Ortaçağ zenginlerinin vebadan kaçmaları gibi, ya kentin merkezini yoksullara bırakarak banliyölere çekildiler ya da kentin merkezindeki işçi mahallelerinden geniş caddeler geçirerek onları kentin dışına sürdüler.” (Bumin, 2013, s.68). Emine Uşaklıgil ise "Bir Şehri Yok Etmek" adlı yapıtında, yok sayılan yoksul ve güçsüz insanların iktidar tarafından kent için bir tehdit olarak göründüklerini, bu nedenle iş ve ekmek kaynakları olan şehir merkezinden kilometrelerce mesafedeki ucuz ve sağlıksız konutlara gönderilip, gözlerden uzak tutulmaya çalışıldıklarını ifade eder.Bunun en somut örneklerinden biri "yenileme projesi" kapsamında Sulukule'de evleri yıkılarak kentin dışına tahliye edilen ve sayıları 3 binin üzerinde olan Roman vatandaşlarını söyleyebiliriz.Aşağıda yerverilen fotoğraf ve Behiç Ak’ın7 kaleme aldığı karikatür, bu durumu farklı açıdan sunmaktadır. (Uşaklıgil, 2014, s.33)

Behiç Ak’ı 2002 yılında yazdığı ve tiyatroda sahnelenen "Tek Kişilik Şehir" adlı oyunu da ayrıca ele aldığı konu açısından dikkat çekicidir. Ak, "Bir gökdelenin en üst katındaki, tek kişilik masalarla dolu bir lokantada geçen oyununda; şehrin merkezinde yapılan ve ilk zamanlarında gözde mekanlar olan gökdelenlerin, zaman içerisinde nasıl intihar kulelerine dönüştüğünü anlatır. Ben merkezci ve her şeyin tek kişilik gereksinimlerin karşllanmak üzere kurgulandığ gökdelenlerden oluşmuş kentler, iki kişiden fazla olan aileler için uygun değildir. Kendilerine tek kişilik şehirde yer bulamayan kalabalık ve yoksul aileler şehrin dışına itilmişlerdir, tıpkı Tahsin Yücel'in "Gökdelen"inindeki yılkı adamları gibi. Bunun için ayrıca bkz: Solak, C. (2012). Bir Ekoeleştiri Denemesi: Behiç Ak’ın Tek Kişilik Şehir Oyununda Birey, Toplum ve Çevre İlişikleri, A.Ü. Türkiyat Araştırmaları Enstitüsü Dergisi (TAED), 47. Erzurum, s.211224.; bkz: http://tiyatronline.com/-tek-kisilik-sehir_-ankara-devlet-tiyatrosu-3588

Adres

Kırklareli Üniversitesi, Fen Edebiyat Fakültesi, Türk Dili ve Edebiyatı Bölümü, Kayalı Kampüsü-Kırklareli/TÜRKIYYE e-posta: editor@rumelide.com
Adress

Kurklareli University, Faculty of Arts and Sciences, Department of Turkish Language and Literature, Kayalı Campus-Kırklareli/TURKEY e-mail: editor@rumelide.com 

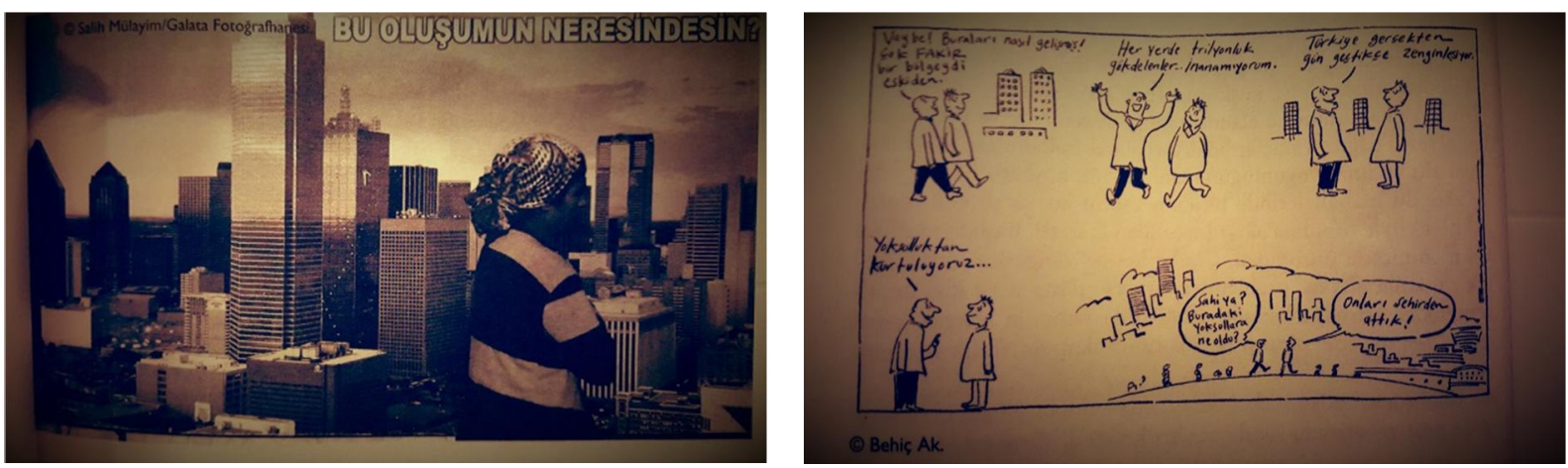

Vay be! Buralar nasıl gelişmiş! Çok fakir bir bölgeydi eskiden.

Her yerde trilyonluk gökdelenler. İnanamıyorum. Türkiye gerçekten gün geçtikçe zenginleşiyor. Yoksulluktan kurtuluyoruz.

Sahi ya buradaki yoksullara ne oldu?

Onları şehirden attık!

Birleşik Devletler'de getto, Fransa'da banliyö, İtalya'da quarteri periferici (dış mahalleler) ya da quarteri degradati (yoksul mahalleler), İsveç’te problemomrade (sorunlu bölgeler), Brezilya'da favela (teneke mahalleler), Arjantin'de villa miseria (sefalet mahalleleri) Metropolü meydana getiren mekânların hiyerarşisinde en altta yer alan, adı kötüye çıkmış bu mahalleleri isimlendirmek için Kuzey Amerika, Batı Avrupa, Güney Amerika toplumlarının topografi lügatlarında özel bir kavram vardır.Toplumsal sorunların birikip irin topladığı, cehennem halesiyle örtülü bu mekânlarda, yeni yüzyılın kent paryaları yaşar. (Wacquant, 2015, s.11) Kent paryaları ya da yılkı adamlarının yaşadıkları yerlerin adları, her uzamda, süremde ve kültürde farklılık gösterse de gerçekte aynı muameleye maruz kaldıkları görülmektedir. Sözgelimi Amerika Birleşik Devletleri’nde bütün kaybedenlerin toplandığı yer olan "slum8" bölgeleri gibi. Geçmişten bugüne kentler ve kent mimarileri belirli zihinsel anlayışların yansımalarıdır. Kentler, kentte yaşayan vatandaşlara bırakılmayacak kadar değerli bulunmuş ve kurgulanmalarında güç ve güç ilişkilerinin büyük rolü olmuştur. "Lefebvre'ye göre kentin özünü genelde kapitalist ilişkilerin hem sonucu hem de yaratıcısı olan mekânsal bir biçim” oluşturur. Dolayısıyla o, iktidarın zaman üzerindeki hakimiyetini oldukça iyi kavramıştır. Dahası gücün ve güç ilişkilerinin zamanla birlikte mekân üzerindeki etkinliği, karşımıza kent çözümlemesi olarak çımmaktadır.” (Çınar, 2013, s.204-205). Özellikle son yıllarda kentsel dönüşüm ya da gelişim projeleri adı altında, şehrin güvenliğini tehdit eden denetimsiz bölgeler ve dolayısıyla bu bölgelerde yaşayan vatandaşlar, kentlerde çözülmesi gereken en önemli sorunlar olarak görülmeye başlanmışlardır. Kent merkezlerinde "çöküntü alanları", "suç alanları", "varoş ve yoksul mahalleri” olarak görülen mekânlar ve bu mekânlarda yaşayan marjinal ve/veya yoksul halk, kent merkezi dışına itilerek, mekânlar üst gelir grubu ve sermayenin kullanımına tahsis edilmiştir. Literatürde soylulaştırma (gentrification) olarak tartışlan bu olgu zorunlu olarak yerinden edilmeyi içerdiği için var olan sosyo-mekânsal ayrışmayı daha da arttırmaktadır. (Tümtaş, 2012, s. 125-126)

“Slum (ABD’de, eski, büyük çoğunluğu terk edilmiş binalardan ve yıkıntılardan oluşan, en yoksul tabakanın ikamet ettiği kent bölgesi.)-okullar, iș, çöp toplama, sokak aydınlatması, kütüphane, sosyal hizmetler ve topluluklara sınırlı ölçüde sunulan her şey için verilen mücadelede kaybedenlerdir.Bkz. Harvey, D. (2013). Sosyal Adalet ve Şehir, 4. baskı. s.77; Ayrıca bkz. Wacquant, "Kent Paryaları Amerika ve Büyük Britanya'da "sinıfaltı", Hollanda, Almanya, Kuzey İtalya'da "yeni tür yoksulluk" Fransa, Belçika, İspanya, belirli İskandinav ülkelerinde "dışlanma”; bu durumu tanımlamak için hangi etiket kullanılırsa kullanılsın ileri marjinalliğin açı göstergeleri Batı metropolünün üstünkörü gözlemcilerine bile hemen tanıdık gelir. 


\section{Sonraki Metin I: Gökdelen ya da Ağaoğlu Maslak 1453 İstanbul Projesi}

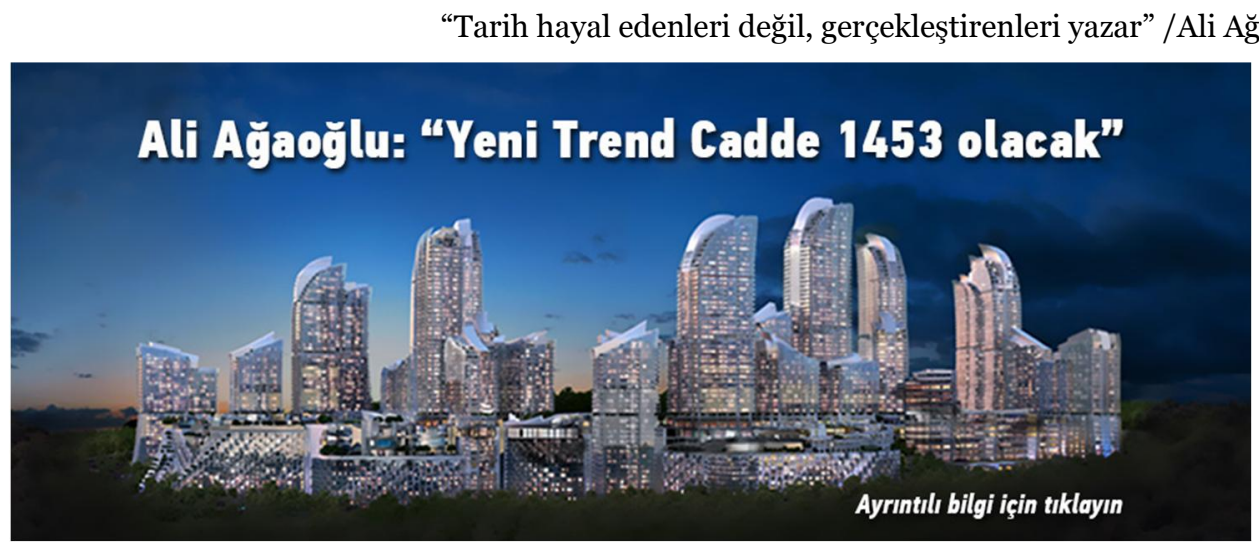

Görsel 1: Yeni Trend Cadde 1453 olacak reklam afişi

Kendisini "hayata geçirdiği projelerle sadece konut değil yaşam tasarlayıcısı" olarak sunan Ağaoğlu Şirketler Grubu Başkanı Ali Ağaoğlu rol aldığı kurumsal tanıtım filminde9 vurguladığı üzere, tıpkı önceki metin karakteri Temel Diker gibi tüm gücünü ve enerjisini İstanbul'u "baştan yaratmaya" adamıştır. Öylesine ki kendisiyle yapılan bir röportajında ${ }^{10}$; bu misyonunu yerine getirme noktasında karşısına çıkan ve engel olarak gördüğü tüm sivil toplum kuruluşlarını -yetki verildiği takdirdeortadan kaldıracağını belirtmekte hiç sakınca görmemektedir. Yine Temel Diker’in yaptırdığı gökdelenleriyle insanları yeryüzündeki pislik ve mikroplardan kurtardığını ve bütün bunların insanların en doğal yaşam hakları olduğunu iddia etmesi gibi "Ali Ağaoğlu da İstanbulluları her türlü "farklılıktan" ve "tehlikeden" uzak, birörnek steril ortamlarda yaşatmak ister. O bir "yaşam mimarı"dır, insanlara en ince ayrıntılarına kadar "tasarlanmış hayatlar" sunar - bizzat kendisinin tasarladığı hayatlar: "Ben Ali Ağaoğlu, burası İstanbul Ayazma, burada 3100 konutluk yeni bir yaşam merkezi kuruyorum. \%87'si yeşil alan olacak, içinde golf sahası bile olacak. Hep hayal ederdim onuncu kattaki evin bahçesi olur mu, yaptım olacak! Çünkü bu ülkede herkes havuzlu, güzel kaliteli bir evde oturmayı hak ediyor. Burada havuzlar olacak. Burada bir meydan var, mağazalar var. Her şey var. Burada bir yaşam var." "1 Temel Diker'in en büyük düşü İstanbul'u ikinci bir New York yapmaktır. Bu nedenle Niyorklu Temel olarak anılır. Ali Ağaoğlu'nun tasarladı̆̆ yaşam modelleri de Amerika Birleşik Devletleri'nden devşirmedir. Kendisiyle yapılan bir röportajda; Amerika Birleşik Devletleri Ankara Büyükelçisi Ross Wilson'a Ataşehir'de yaptığı My World projesini gezdirdiğini ve Wilson'ın böyle bir projenin ABD'de bile olmadığını söyleyerek, kendisinin ünlü emlak kralı (reklamın çekildiği zaman Donald Trump henüz Başkan değildi, 8 Kasım 2016 ABD seçimleri sonucuna göre seçilmiş günümüz ABD Başkanı'dır.) Trump'tan daha iyi olduğunu söylemiştir. ${ }^{12} \mathrm{Bu}$ nedenle Trabzon'un Of ilçesinden olan Ali Ağaoğlu kendisini "Oflu Trump” olarak sunmakta bir sakınca görmemektedir. Bir anlamda kurgusal Niyorklu Temel ve gerçek Oflu Trump yaptırdıkları ev ve gökdelenler ile Amerikan yaşam tarzını Türk toplumuna benimsetmeye çalışan birer yaşam kurucuları/mimarları rolünü üstlenmişlerdir.

\footnotetext{
9 https://www.youtube.com/watch?v=RQaqQHse2Uk (Ağaoğlu Şirketler Grubu Kurumsal Tanıtım Filmi, erişim tarihi:11.02.2020)

10 Ezgi Hazar'ın "İstanbul'u Baştan Yaratanlar, Niyorklu Temel ile Oflu Trump", adlı yazısından alıntıyla http://www.cnnturk.com/2011/cnn.turk.tv/o3/25/mimarlar.agaogluna.tepkili.ozur.dile

11 Hazar, E (2012); “İstanbul'u Baştan Yaratanlar, Niyorklu Temel ile Oflu Trump”, http://www.eskop.com/skopbulten/istanbulu-bastan-yaratanlar-niyorklu-temel-ile-oflu-trump/479 
Romanda haber ve televizyon programlarıyla projelerini -daha doğrusu projeleri için hukukun özelleştirilmesi” gereğini kamuoyuyla paylaşan Temel Diker’in ekibine karşılık; Ali Ağaoğlu reklam filmiyle konut projesini kitleye ulaştırır. Kurgusal roman karakterimiz Temel Diker medyada kendisi yerine avukatı ve seçili gazetecileri kullanırken, Ali Ağaoğlu projesinin reklam yüzü olarak bizzat kendisi ekranlarda ve gazetelerde boy gösterir. Ağaoğlu'nu sadece Maslak 1453 konut projesinin reklamında değil, diğer konut projelerinde de görürüz. ${ }^{13}$ Reklam ve halkla ilişkiler çalışmalarında Ağaoğlu, Türk’ün de vurguladığı üzere "vaad ettiği şeyleri bizatihi kendi varoluşunda temsil ederek kitleye sunar" (Türk, 2016, s. 101-111) Vaat ettiği yaşam alanlarına herkesin daha rahat ve daha kısa zamanda ulaşabilmesi için Ağaoğlu Türkiye'ye Sesleniyor'14 adıyla çektirdiği reklam filminde "Herşeyi devletten beklemek olmaz. Banka faizinin \%35’ini ben ödüyorum... Destek öyle olmaz böyle olur." diyerek bir nevi devlet başkanlarının televizyondan yaptı̆̆ "ulusa sesleniş" türünden konuşma gerçekleştirir. Büyük düşünü bir an önce gerçekleştirmek isteyen Temel Diker de Ağaoğlu gibi kişileri ev sahibi yapma konusunda her türlü kolaylı̆̆ı sağlar. "Gerek kendi kuruluşunun sorumlularına, gerek kendi tasarımını uygulayan yüklenicilere de insanlara olanaklarının elverdiği ölçüde yardımcı olmalarını söyler. Böylece kimi istekliler büyük indirimlerden yararlandırıldı, kimilerinin sorunu çok elverişli taksitlerle çözüldü.” (Yücel, s. 2006, 245)

İlk kez 2012 Ekim’inde televizyonlarda yayınlanmaya başlayan ve yönetmenliğini Sinan Çetin’in yaptığı, başrollerinde ise Ali Ağaoğlu'nun oynadı̆̆ıMaslak 1453 İstanbul15(reklam tanıtımının yapıldığı ve ekranlarda göründüğü zaman, projenin web sayfasında yer alan metindir.)reklamları, özellikle Ağaoğlu'nun reklamda sarfettiği tümceler ve kendisini 1453’te İstanbul'u fetheden Osmanlı padişahı Fatih Sultan Mehmet'e benzeten (nitekim kendi projesinin adı da Maslak 1453’tür.) at üstündeki görüntüsüyle dikkatleri çeker.

Bkz: https://www.youtube.com/watch?v=sBkZRMljsgo (Maslak 1453 reklam filmi; “ Yeni İstanbul Fatihi Ali AğaoğluBu değil!, erişim tarihi:11.02.2020); https://www.youtube.com/watch?v=pr3E9PNBY4c (Ağaoğlu my home Maslak, erişim tarihi:11.02.2020); https://www.youtube.com/watch?v=_yNT40Gyi5M (Ağaoğlu my World Europe), erişim tarihi:11.02.2020); https://www.youtube.com/watch?v=XBjHzml5INU (Ağaoğlu My World, erişim tarihi:11.02.2020) https://www.youtube.com/wath?v=GsLZH9x_DuY (Ağaoğlu Türkiye'ye Sesleniyor reklamı, erişim tarihi:11.02.2020) Maslak 1453 İstanbul Projesi kendi web sayfasında yayınlanan tanıtım metninde de ideal ve herkesin yaşamak istediği bir yaşam alanı olarak kurgulanmıştır: "Büyük şehirde hayat dinamiktir, hareketlidir. Eğlencelidir. Bunun için çekicidir. Kültür zenginliği, yiyecek içecek çeşitliliği, alıșveriș seçenekleri, gece hayatı, moda, sanat hep hızlı bir devinim içindedir. İstanbul, bütün bu özelliklerin fazlasını kendinde toplayan, dünyanın en önemli metropollerinden biridir. Hem sakinleri, hem de ziyaretçileri için özeldir. Çok caziptir. Buna karșın çok geniş bir alana yayılmıs olması, trafik, kalabalık, ulaşım sorunları bu cazibeyi zor ulaşılır ya da ulaşılmaz kılmaktadır. Bir zamanlar tiyatro ve sinemalar, kültür ve alışveriş merkezleri, lokanta ve eğlence yerlerini barındıran Pera, "ana cadde" özelliğiyle, şehrin özgün kalitesini yasatıyordu. Cevre pasajlar ve ara sokaklar da yiyecek icecek, kültür ve eğlence uzantıları olarak bu canlılı̆̆ tașıordu. Göçlerle kalabalıklaşan şehrin merkezindeki beklentiler değiştikçe, bu kaliteli yaşam da ana caddeden uzaklaştı. Anadolu yakasında Bağdat Caddesi öne çıksa da ulaşım yüzünden tam bir alternatif olamadı.

Gelişen alışveriş merkezleri ve çevreye kapalı yeni yerleşimler şehrin zenginliğini böldü. İstanbul'a gelenler özlemini çektikleri büyükşehir yaşantısı yerine merkezden kopuk bir hayatla karşılaşıyor, devinimi uzaktan seyretmek zorunda kalıyorlar. Ağaoğlu Maslak 1453 İstanbul iște tam da bu eksiği giderecek, bu özleme cevap verecek projedir. Şehir merkezi, ana cadde olgusunu bir çekim merkezi olarak hayata geçirecek, kültür, sanat, yeme içme, eğlence ve gece hayatını en başta kendi sakinleriyle hareketlendirecek bir yapıdır. Bu devinimin yanında çok önemli bir de konum avantajı da vardır. Kuzeyden Fatih Ormanı'na komşudur. İlginç ve eşine az raslanır bir șekilde, hem büyük șehir özelliklerini, hem de sürdürülebilir kaynakları ve çevreye duyarlı yeşil bina sistemlerini bünyesinde barındıran ender bir yapidır." 


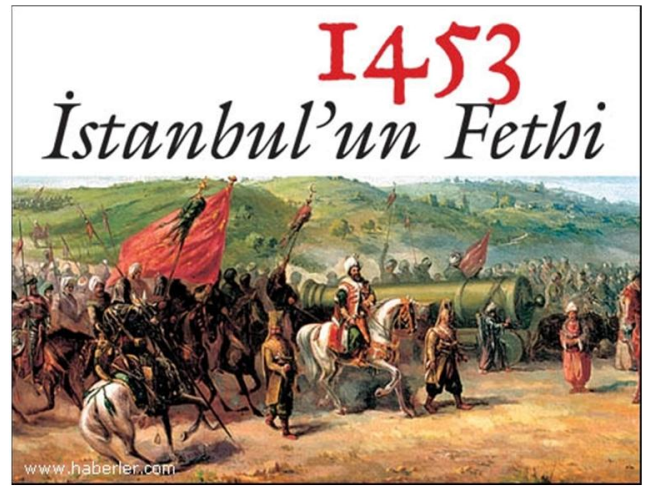

Görsel 2: F. S. Mehmet’in İstanbul'u fethetme temsili

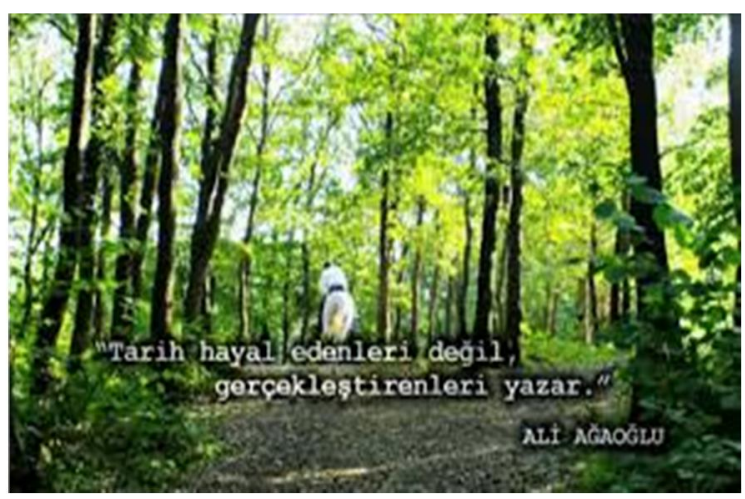

Görsel3: Ali Ağaoğlu Maslak 1453 reklam filminden bir kare

Gökdelen'de Temel Diker yani Niyorklu Temel, Sarayburnu'na yapmak istediği anıt için, Topkapı Sarayı'nın bahçesinin 'azıcık kırpılması, denizin azıcık doldurulması, yolun bir bölümünün de tünele dönüştürülmesi’ gerektiğini ilan eder. Fakat Koruma Kurulu bu plana karşı çıkar, nitekim kısa bir süre sonra, yargı özelleştirilir ve Kurul da ortadan kalkar. Böylelikle Temel Diker’in projesi için hiçbir engel kalmaz. Herkese -elbette yoksul ve güçsüzlerin dışındaki-herkese daha iyi yaşama hakkı vaat eden Oflu Trump’ı da Maslak 1453 projesi için açlan davalar sıkar, üzer ancak herşeye rağmen mahkemenin yürütmeyi durdurma kararından sonra şirket tarafından revize edildiği söylenen imar planı, Çevre ve Şehircilik Bakanlığı'nın onayından geçmiş olduğu için- inşaatlar devam eder ve 2016 Eylül'ünde yaşam başlar. Öylesine ki 2016 yllında Maslak 1453 Projesi Emlak Konut GYO KAP Raporu'na göre '2016 yılının hasılat paylaşım modeliyle gerçekleşen projelerde 2016 satış rekortmeni olur.'16 Bu kazançlı edinimler ise Niyorklu Temel gibi, "Bu ülkede herkes iyi yaşamayı hak ediyor" savıyla hayalini gerçekleştirmek için yola çıkan Oflu Trump Ali Ağaoğlu'nun da amacına ulaştığını gösteriyor.

\section{Sonraki Metin II: Devler (Gökdelenler) Arasında Bir Kahraman}

Suriçi planımız için bir maket hazırlattım sizler için. İşte İstanbul'un geleceği burada. /Timur Arslan

Köyden kente göçün yoğun olarak başladığı 1960'lardan günümüze, gecekondulaşma ve kentsel dönüşüm adı altında büyük şehirlerde bir yapılanma söz konudur. Özellikle bütün göçlerin ve kentsel değişimlerin merkezi konumundaki İstanbul, en önemli aktarım aracı sinemada da çok sayıda filme bu yönüyle konu olmuştur. Makalede ise günümüz İstanbul'unda geçen ve yönetmenliğini Burak Aksak’ın yaptı̆̆ı 2015 yapımı "Bana Masal Anlatma" filmi ele alınmaktadır.

Film, Suriçi’nde yaşayan ve Suriçi-Taksim arasında minübüs şöförlüğü yapan Rıza ile bir gece yarısı tarihi surların ${ }^{17}$ içinden çıkagelen masal kızı Ayperi arasındaki aşkı anlatmaktadır. Filmin yüzey yapısında Rıza'nın Ayperi'ye olan aşkı ve masal prensesi Ayperi'ye kendisini bir masal kahramanı

16 www.agaoglu.com.tr/tr/newsDetails/2016-satis-rekortmeni-maslak-1453-oldu (erişim tarihi: 02.12.2019)

17 İstanbul surları, sehrin çevresinde bulunan, Bizans İmp. Zamanında sehri korumak için yapılan duvarlardır. İstanbul'un etrafını çeviren surlar tarihte 5. Yüzyıldan başlayarak inşa edilmiş, yıkılmalar ve yeniden yapımlar ile dört defa yenilenmiştir. Son yapımı MS. 408'dir. II. Theodosius (MS 408-450) zamanında İstanbul surları Sarayburnu'ndan Haliç kıyısı boyunca Ayvansaray'a, Marmara kıyısı boyunca Yedikule'ye, Yedikule'den Topkapı'ya, Topkapı'dan Ayvansaray'a uzanıyordu. Yıllar içerisinde surların bazı kıısmlarına küçük restorasyonlar yapıldı. (http://aktuelarkeoloji.com.tr/istanbulun-surlari-can-cekisiyor erişim tarihi: 08.02.2020) 
olarak kanıtlama çabası görünsede, derin yapısında herkesin birbirini tanıdığı, mahalle kültürünün egemen olduğu Suriçi’ni-yeni yaşam alanlarıyla değiştirmek isteyenlere (Timur Arslan ve yabancı ortaklarına) karşı- koruma mücadelesi bulunmaktadır.

Film, adına karşıt olarak (Bana Masal Anlatma) daha jenerikten itibaren babanın oğluna (Rıza) anlattığı masalla ${ }^{18}$ başlar. Rıza'nın çocukluğunda dinlediği masalın, yıllar sonra gerçeğe benzer bir biçimde yaşamıyla örtüşmesi ise filme mitsel bir anlam katmaktadır. Masal prensesi Ayperi gerçek zamanın çok ötesinden yine kendisi gibi kökleri çok eskiye uzanan surların arasından çıkagelir. Bir başka ifadeyle anne ve babasını kılıçtan geçirerek öldüren ve kendisini de öldürecek olan sultanın kötü adamlarından kaçarken zamansal bir geçişle surların içinde, Rıza'nın yanında bulur kendini ve ona sığınır. Ayperi’nin tehlikeden kaçarak sığındığı İstanbul surları (üstelik zamansal atlamayla) Rıza'nın da mutlu ya da mutsuz olduğunda sığındığı yerdir. (Ayperi'yle karşılaşmadan önce sevdiği kız olan Ezgi'yle ilk konuşmasından sonra onu surlara götürür; kızın nişanlı olduğunu öğrendiğinde de yine surlara sığınır. Ayperi’yi Timur Arslan'ın oğluyla birlikte gördüğünde üzülür ve öfkesini sur duvarlarına haykırır.) Bu bağlamda sur doğma büyüme Suriçili Rıza için "olanakların, bulusşmaların, beklenmedik olanın mekânı, "rastlantısal ve öngörülemez farklılıkların karșlașma" (Dorso, 2019, s. 6) alanıdır. Özellikle bir türlü Ezgi’yi sevdiğini söyleyemeyen Rıza, onu surların olduğu tepeye götürür. Surların içinde şehre doğru baktıklarında aralarında geçen şu diyalog makalenin konusu çerçevesinde ele alındı ̆̆ında oldukça önemlidir:

Rıza: Şehirler de insanlar gibidir derdi babam, zamanla değişir.

Kız: Ya bu değişim gibi de değil. Baksana şu şehre, sanki ölüyor gibi.

Rıza: İnsanlar gibi işte. Babam öldü mesela. Şehirler niye ölmesin? Gökdelenler de şehrin mezar taşı bir nevi.

Kız: Mezartaşı...bence en güzel tanım bu.

18 Evvel zaman içinde kalbur saman içinde bilinmez yeri zamanı belki ta şurası belki Kaf Dağı’nın arkası... Zamanlardan bir gün Ayperi adında bir kız yaşarmış. Peri kızı değil sıradan bir demirci ustasının kızıymış ama güzelliği o kadar konuşulmuş o kadar yayılmış ki her diyardan onu görmek için gelenler varmış. Yiğitler Ayperi uğruna kılıç kuşanıp cenk etmiș. Bütün diyarların hakimi olan sultanlar sultanın da evlilik çağına gelmiş genç bir kızı varmıș. Kız evlilik çağına gelmiş gelmesine ama yanına gelen hiçbir yiğit yokmuş. Genç kızın ağlamaktan göz pınarları kurumuş, Sultan çok sinirlenmiş bu duruma. Hemen askerlerini göndermiș Ayperi kızın evine. Ayperi’nin babası atllların geldiğini görünce hemen kızı ve karısına kaçın demiş. Ayperi gitmek istememiş, sarılmış babasına. Askerler içeri girmiş, Ayperi’nin gözleri önünde anne ve babasını öldürmüşler. Askerlerden bir tanesi kılıcını Ayperi’nin yüzüne doğru savurmuş, yüzü çizilmiş, bir damla kan düssmüs yere. Kanın düștüğü yerde çiçek filizlenmiș. Asker Ayperi’nin gözlerine bakınca kılıcı düșmüss. Koș diyebilmiş sadece. Kaç git buralardan. Koşmuş Ayperi bilmediği yollardan geçmiş, tatmadığı sulardan içmiş. Sonunda bir çadır bulmuş. Çadıra girdiğinde içerdeki yaşlı bir adam: Hoş geldin Ayperi demiş. Ayperi şaşırmış. Adımı nereden biliyorsun diye sormuş. Adam büyücüymüss. Seni bu esaretten kurtaracak olan adam senin kahramanındır. Bu kişi gökte ay tabak gibi kaldı̆̆ı bir gece, devlerin içinden sıyrılıp, ateşlerin arasından çıkıp gelecek. Senin için herşeyini feda etmeye hazır olan, yüzünde seninki gibi bir yara izi olan kahraman seni öpecek ve esaretini sona erdirecek.

Kurklareli University, Faculty of Arts and Sciences, Department of Turkish Language and Literature, Kayalı Campus-Kırklareli/TURKEY e-mail: editor@rumelide.com 


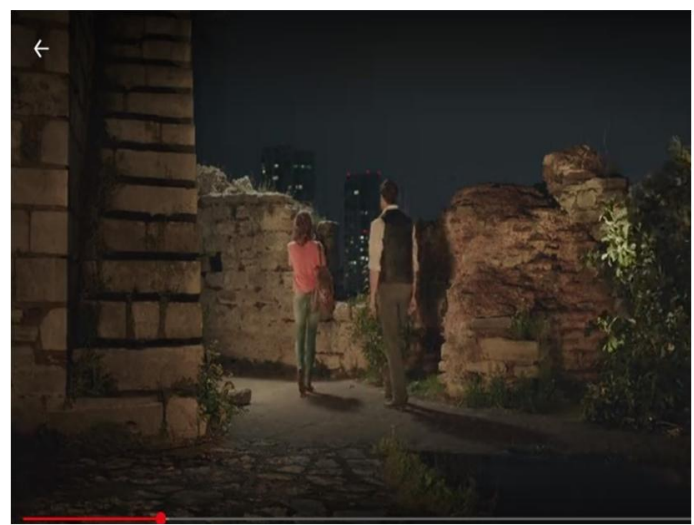

Görsel 4: Sur ve gökdelenler

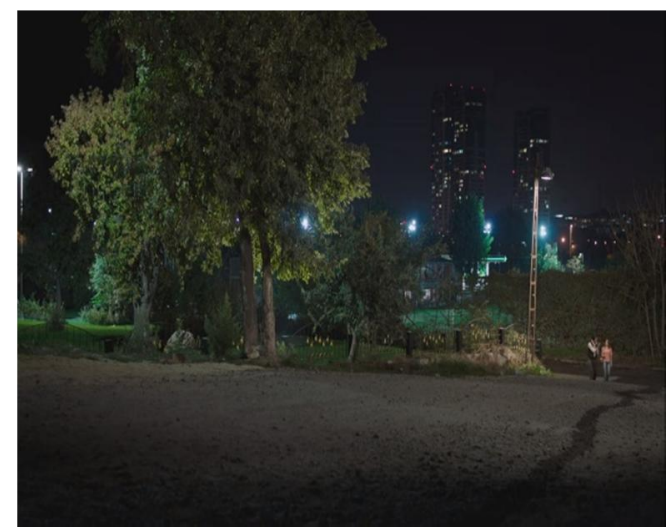

Görsel 5: Uzaktan mezartaşı gibi görünen gökdelenler

Filmden alınan görselde de görüleceği gibi surlar bir çeşit sınırdır. Bir yanda yapımı çok eskiye dayanan ve kenti korumak için yapılan İstanbul'un kara surları, öte yanda yüksek yüksek gökdelenler. Işıltılı yüksek binalar şehrin yeni halini temsil ederken, Rıza ve doğup büyüdüğü Suriçi eskiyi ve geleneği temsil etmektedir. Ancak "kenti koruyan, ayıran, kentsel gelişmeyi çerçevelendiren bir sınır işlevi gören, tarihi İstanbul surları" (Dorso, 2019, s. 44)artık ölmek üzeredir hatta ölmüştür. Surun öte yanında dikilen ve modern İstanbul'u(!) mekânsal olarak temsil eden koca koca gökdelenler ise şehrin mezar taşı olmuştur. İstanbul kentini yapan, kenti tanımlayan ve yüzlerce yll koruyan surlar artık inşaat firmalarınınyeni kentsel alanıdır.

Gökdelen'de (önceki metin) Temel Diker ve Maslak 1453 İstanbul (sonraki metin I) reklam filminde Ali Ağaoğu'na karşıllk "Bana Masal Anlatma"da (sonraki metin II) Tarsan Holding sahibi Timur Arslan’ı görürüz. Timur Arslan'ın da en büyük düşü, tarihi şehri yenilemektir. Uluslararası ortaklarıyla yaptığı yemekli toplantıda da bu fikrini açıklar: "Görmüş olduğunuz güzel İstanbul'umuzda yenilenmeyi bekleyen daha pek çok yerimiz var.” Yeniye yer açmak için eskilerden kurtulmak gerekir. Timur Arslan'ın eski yapılar yerine koca koca yeni gökdelenler dikmek istediği mekân ise tarihi Suriçi'dir. Nitekim ortaklarına satmayı düşündüğü projesini gösterirken şu tümceleri kullanır: "Suriçi planımız için bir maket haztrlattım sizler için. İşte İstanbul'un geleceği burada."

Niyorklu Temel'in düşünü hayata geçirmesini geciktiren ve hatta engelleyen Hikmet Hoca'nın evi gibi, bütün suriçini almış olmasına karşın Timur Arslan da bir engele takılır: Madam'ın evi. Madam da Hikmet Hoca gibi evine karşılık vaat edilen parayı kabul etmemiş, direnmiştir. Rıza, kahvede mahalleliyle yaptığı konuşmada şu tümceyi sarf eder: "Madamm evini sattn almak istiyorlarmsş. Kadın da satmak istemiyorum dedikçe hergün gelip fiyat arttrryyorlarmış." Hatta yıkım konusunda kendisini sürekli taciz eden Timur Arslan'ın adamlarını korkutmak için tüfekle bekler. Gökdelen'de Hikmet Hoca'nın öldürülmesine neden olan da, kendisini zorla evinden çıarmak isteyen güvenlik güçlerine karşlık baba yadigârı tüfeğiyle saldırmasıdır. Timur Arslan ve adamlarına karşı "anılarını ve geçmişi” korumak adına sonuna kadar mücadele eden Madam eceliyle ölmüştür. Ancak evi Timur Arslan'ın adamları tarafından yakılmaktan kurtulamamıştır. Ali Ağaolu ise yeni yaşam alanları yapmak için çevrecilerin ciddi mücadelesine rağmen Fatih Ormanları'nda doğaya zarar vermiştir. (Hikmet Hoca'nın yıktırılan evi/ Madam'ın yakılan evi/ Kesilen ormanlık alanlar, değiştirilen yollar) Her üç anlatıda da yaşam mimarlarımızın önündeki hukuki 
engeller kaldırılmıştır. Filmde de herhangi bir hukuki engelin olmadığını Timur Arslan'ın yabancı ortaklarıyla arasında geçen diyalogdan öğreniriz:

Yabancı ortak: Bir sorun çıkmaz değil mi?

Timur Arslan: Hiç merak etmeyin gerekli izinler alındı.

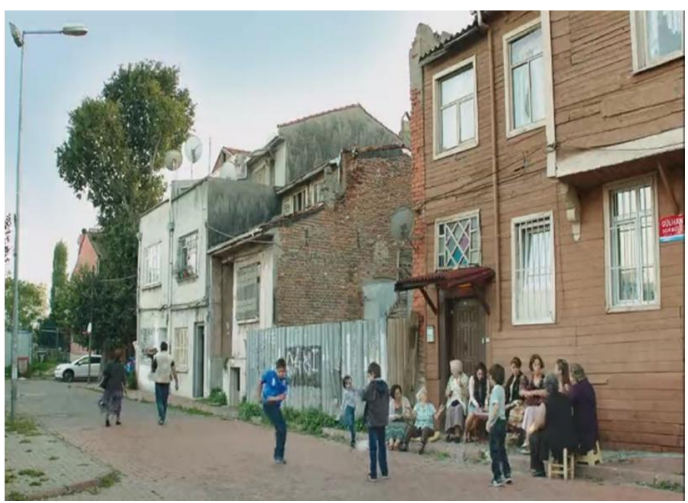

Görsel 6: Madam’nn evi/Gündüz

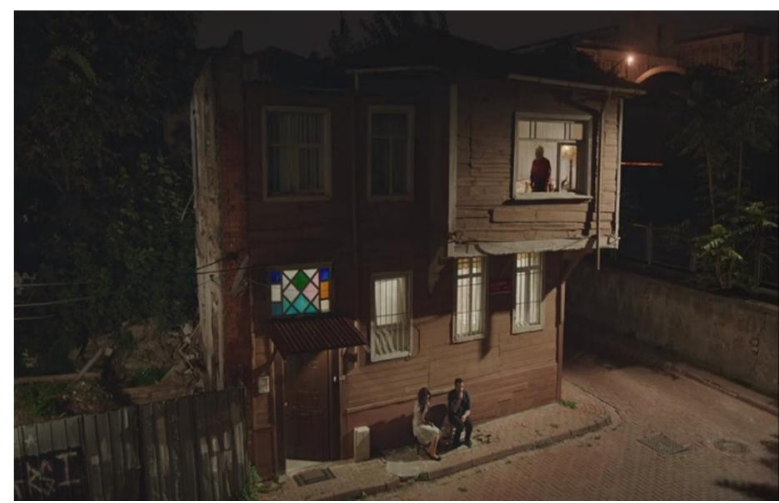

Görsel 7: Madam’nn evi/ Gece

Madamı evini satması yönünde ikna etmek için kırmızı spor arabasıyla gelen Timur Arslan'ın oğlu Erdil, Madam'ın evinde kalan Ayperi'yi görünce şaşırır. Ayperi, Erdil'in kendisini kurtaracak masal kahramanı olduğunu düşünür. Erdil daha en baştan bir masal kahramanı gibi davranmaktansa, babası Timur Arslan'ın adamlarının ateşe verdiği evde Ayperi olmasına karşın, onu kurtarmak yerine hiç düşünmeden kaçar. Oysa 'kahramanın öz niteliği, cesaret ya da soyluluktan çok, kendini bir amaç uğruna feda edebilme gücüdür. Fedakârlık, kahramanın idealleri uğruna değerli bir şeyden, belki de kendi hayatından vazgeçmeyi göze alması demektir' (Tecimer, 2005, s. 124). Doğup büyüdüğü mahallesinin yıkılmaması için tek geçim kaynağı minübüsünü satan (bir amaç uğruna feda etme) Rıza, bu sefer de ölmek pahasına (yaşamından vazgeçerek fedakârlık edebilme gücü ve cesareti) hiç düşünmeden kendisini alevlerin arasına atar ve Ayperi'yi kurtarır. Bir anlamda masal gerçeğe dönüşür. Masaldaki kötü kalpli devler, günümüzde gökdelenler uğruna yakan, yıkan, mahallelinin üzerine adamlarını yollayan yeni yaşam mimarları Timur Arslan ve oğlu Erdil'dir. Rıza ise devlerin/gökdelenlerin neden olduğu ateşlerin arasından geçerek güzeller güzeli masal prensesini ve mahallesini kurtaran kahraman.

\section{Sonuç ve değerlendirme:}

Anlatı karakterlerine ad vermek, genellikle metni üreten tarafindan kimi örtük anlamsal ve simgesel ilişki/çağrışım kurmaya yöneliktir. Makalede konu olan her üç metnin karakter adlarında (her ne kadar reklam metninde gördüğümüz Ali Ağaoğlu, gerçek bir karakter olsa da, kendisine seçtiği ve kamuoyunda kendisiyle anılan "Oflu Trump" adının da simgesel olduğunu göz ardı etmemek gerekir) sözcük oyunuyla ya da verilen isimlerle nedenli bir ilişki kurulduğu görülür. Bu bağlamda yazar (Tahsin Yücel), yönetmen/senarist (Burak Aksak) ve Ali Ağaoğlu'nun kendisi sessel, anlamsal ve simgesel bir kavram yaratır (Kıran ve Kiran, 2011, s.192).

Tahsin Yücel'in Gökdelen'de müteahhit karakteri için seçtiği "Temel Diker” adıyla mesleği arasında çağrışımsal/ilişkisel anlam söz konusudur. "Bir yapının toprak altında kalan ve yapıya dayanak olan duvar, taban ve benzeri bölümlerinin tümü; bu bölümleri yapmak için kazllan çukur; bir şeyin gelişimi için gereken ilk öğeler...” (Püsküllüoğlu, 2002, s.1482) anlamlarına gelen temel sözcüğüyle, işi gereği 
Following the paths of the new life architectures in cinema and commercials in the context of Tahsin Yücel's Gökdelen / R. Köse Özelçi (pp. 279-296)

çok yüksek yapılı binaların temellerini atan ve diktiği binaların her yerde istediği şekilde yüksel mesi/ çoğalması için uğraş veren Temel Diker’le birebir örtüşmektedir. Öte yandan inşaat sektörünün ülkemizde en çok Karadeniz Bölgesi'nde olduğu dikkate alındığında'19 ve yine çok sayıda Karadeniz fikrasında geçen, yörenin simge isimlerinden biri olan "Temel" adı; her açıdan karakterin toplumun hafızasında yer edinen Karadenizli müeahhit algısını desteklemektedir.

Önceki metin karakteriyle, sonraki metin I'deki Oflu Trump lâkabıyla tanınan Ali Ağaoğlu arasında adları açısından metinlerarası ilişkisel bağ kurulabilir. Müteahhitlerin çoğunluğunun Trabzon'un Of ilçesinden olduğu (Karyelioğlu, 2015, s.207-240) ülkemizde Ali Ağaoğlu'nun da Temel Diker gibi Karadenizli müteahhit yönü, kendisinden önceki metinle benzerlik ilişkisini devam ettirir. (Oflu) Trump ise -her ne kadar günümüzde ABD Başkanı olarak bilinse de- asıl mesleği inşaat ve emlak sektörü olan New Yorklu Donald Trump’a gönderme yapar, Temel Diker'in lâkabı da Niyorklu Temel'dir.

Sonraki Metin II'de müteahhit karaktere verilen "Timur" adı ise tarihteki Timur'u hatırlatır. 1402 yılında Osmanlı Padişahı Yıldırım Beyazıt’la karşı karşıya geldiği Ankara Savaşı’nda, Osmanlı ordusunu yenilgiye uğratan ve geçtiği yerleri yakan, yıkan Timur gibi; müteahhit Timur Arslan da Osmanlı'dan günümüze kadar kalan tarihi Suriçi’ni, istediği binaları dikmek için yakıp- yıkmaktan sakınmaz. (Madam'ın tarihi evini yaktırması; Suriçi’nde yaşayan mahallelinin üzerine hiç çekinmeden adamlarını göndermesi gibi)

Gökdelen'de başta medya organları olmak üzere, parasal güce sahip patronların ve siyasal olarak ülkeyi yönetenlerin arasındaki çıkar ilişkileri sonucu yargının özelleştirilmesi süreçlerini ele alan Tahsin Yücel, hayallerin gerçekleşmesini engelleyen bütün yasalar ve insanların yine hukuk eliyle oldukça kolay pazarlanabilen birer metaya dönüştürüldüğünü göz önüne seriyor.

Gökdelen'de olduğu gibi, Suriçi’ndeki projeler için (yılkı adamlarının, yoksulların, kent paryalarının da sahip olduğu alanlar) konutlar yeniden dönüştürülmek üzere güçlü inşaat firmaları tarafından satın alınır ya da satmayanlar zorla çıkarılır. Maslak 1453 İstanbul için ise belediyelerin sınırları değişir. Her üç yaşam mimarı da yaptıkları konut projeleriyle tarihe geçmek isterler. Ali Ağaoğlu, "Tarih hayal edenleri değil, yapanları yazar" savsözüyle, 1453 yılında İstanbul'u alarak dünya tarihinin en önemli fethini gerçekleştiren Fatih Sultan Mehmet’e öykünürcesine Fatih Orman manzaralı Maslak 1453 konut projesini yapar. Bir anlamda yaptırdı ̆̆ı yaşam alanı projeleriyle tarihe geçtiğini vurgular. Temel Diker varlı̆̆ını 1886 yılında yaptırılan ve Amerika'nın en önemli simgesi olan Özgürlük Anıtı’nın üçdört katı büyüklüğ̈̈nde bir heykeli (annesinin) yaptırararak kantlamak ister. Timur Arslan ise binlerce yllık geçmişe sahip tarihi İstanbul surlarının içini yeniden düzenlemek gayesindedir. Yeni yaşam alanları kurmak için her yolu deneyen kurgusal anlatı karakterleriyle (Gökdelen/ Bana Masal Anlatma) gerçek karakter (Maslak 1453) arasındaki tek farklılık ise görüldüğü üzere adlarıdır.

\begin{tabular}{|c|c|c|c|c|}
\hline $\begin{array}{c}\text { Önceki metin } \\
\text { Gökdelen } \\
\text { (Roman) }\end{array}$ & $\begin{array}{c}\text { Niyorklu Temel } \\
\text { Diker “Benim tek } \\
\text { derdim bu kenti } \\
\text { yeniden kurmak." }\end{array}$ & $\begin{array}{c}\text { Ayasofya, Topkapı } \\
\text { Sarayı'nı yıma } \\
\text { pahasına inşaatlarla } \\
\text { yeniden İstanbul'u }\end{array}$ & $\begin{array}{c}\text { Hikmet Hoca } \\
\text { engeline karşıt/ } \\
\text { Yargının } \\
\text { özelleştirilmesi }\end{array}$ & $\begin{array}{c}\text { Şehrin dışına atılan } \\
\text { yllkı adamlarının } \\
\text { şehre geri dönüşü }\end{array}$ \\
\hline
\end{tabular}

19 Kamu tarafindan uygulanan ekonomik politikaların da büyümesine katkıda bulunduğu ins,aat sektö- rünün temel aktörleri olan müteahhitlerin, özellikle bazı coğrafyalarda diğerlerine göre daha yoğun faaliyet gösterdiği görülmekte, dahası meslek olarak müteahhitliğin yaygınlı göstermesi bazı yörelerde daha yoğun rastlanan bir durum arz etmektedir. Söz konusu coğrafyalardan biri de Karadeniz bölgesi olup, özellikle Trabzon bu konuda öne çıkan kentlerden biri görünümündedir. Bu konuda bkz: Karyelioğlu, S. (2015). Türkiye'de İnşaat Sektörünün Gelişimi Bağlamında Trabzon'da Müteahhitliğin Sosyo-Kültürel Temelleri. Karadeniz İncelemeleri Dergisi. (19) s.207-240. 


\begin{tabular}{|c|c|c|c|c|}
\hline & & yaratma & & \\
\hline $\begin{array}{l}\text { Sonraki metin I } \\
\text { Maslak } 1453 \\
\text { İstanbul } \\
\text { (Reklam Filmi) }\end{array}$ & $\begin{array}{l}\text { Oflu Trump Ali } \\
\text { Ağaoğlu } \\
\text { “Tarih hayal } \\
\text { edenleri değil, } \\
\text { gerçekleştirenleri } \\
\text { yazar.” }\end{array}$ & $\begin{array}{l}\text { Kentsel dönüşüm ve } \\
\text { yenileme projeleriyle } \\
\text { Fatih Ormanı'ndan } \\
\text { ağaçlar kesme } \\
\text { pahasına İstanbul'da } \\
\text { "Yeni yaşam alanları" } \\
\text { kurma isteği }\end{array}$ & $\begin{array}{l}\text { Çevre örgütleri ve } \\
\text { STK'ların } \\
\text { mücadelesine } \\
\text { karşıt/ yargı yoluyla } \\
\text { Belediye sınırlarının } \\
\text { değiştirilmesi }\end{array}$ & $\begin{array}{c}\text { Yoksullar, } \\
\text { güçsüzler, kent } \\
\text { paryalarının lüks } \\
\text { yassam alanlarının } \\
\text { dışına atılması } \\
\text { (zengin /yoksul } \\
\text { ayrımı) }\end{array}$ \\
\hline $\begin{array}{l}\text { Sonraki metin II } \\
\text { Bana Masal } \\
\text { Anlatma } \\
\text { (Sinema Filmi) }\end{array}$ & $\begin{array}{c}\text { Timur Arslan “İşte } \\
\text { İstanbul'un geleceği } \\
\text { burada." }\end{array}$ & $\begin{array}{c}\text { Tarihi Suriçi'ndeki } \\
\text { evleri yıkarak, çok } \\
\text { uluslu ortaklıklarla } \\
\text { İstanbul'da yeni } \\
\text { yapılar kurma isteği }\end{array}$ & $\begin{array}{l}\text { Madam Eleni’ye } \\
\text { karşıt/ evin } \\
\text { yakılması; Suriçi } \\
\text { sakinlerine baskı } \\
\text { yoluyla alınması, }\end{array}$ & $\begin{array}{c}\text { Yoksullar, } \\
\text { güçsüzler, mahalle } \\
\text { sakinlerinin } \\
\text { mücadele etmesi }\end{array}$ \\
\hline
\end{tabular}

Tablo 1: Metinlerarası ilişkiler bağlamında Önceki metin/ Sonraki metin I/ Sonraki metin II

G. Genette'nin metinlerarası ilişkiler yaklaşımı bağlamında ele alınan üç farklı anlatı metninde (roman, reklam, sinema); Genette’in "sürekli dolaşım halindeki yazın" (Kıran ve Kıran, 2011, s. 363) adını verdiği bir metnin bir ya da birkaç düzeyde diğer metinlerle ilişki kurabileceği (karakter kurgusu; karakter adları, karakterin amacı, eylem alanı gibi) saptamasının yapıldı̆̆ı makalede; kentlerin artık satılan ve pazarlanan en değerli "ürünler" kategorisinde yer aldığı yenidünya düzeninde, Gökdelen'deki yılkı adamlarının şehre dönüşü ya da Bana Masal Anlatma'da Rıza'nın tanımlamasıyla "sur içinde sıkışıp kalmış, tarihin hiçbir zaman yazmayacağı" bireyler olmalarına karşın, her köşesinde tarihin olduğu İstanbul'a fedakârlık yaparak sahip çıkmaları kurgusal dünyada umut vericidir. Buna karşın gerçek dünyada gerçek müteahhitler tarafından (Oflu Trump) kentin tarihi dokusu, doğası ve hafızası durmaksızın değiştirilmeye devam etmektedir.

\section{Kaynakça}

Aksak, B. (Yönetmen/Senaryo). (2015). Bana Masal Anlatma (Film). BKM.

Aktulum, M. (2018). Sinema ve Metinlerarasılık, Filmlerarası Etkileşimler ve Aktarımlar. İstanbul: Çizgi Kitabevi

Avşar, Z., Demir, V. (2005). Düzenleme ve Uygulamalarla Medyada Denetim. Ankara: Piramit.

Bumin, Kürşat (2013). Demokrasi Arayışında Kent. 2. Baskı. Konya: Çizgi.

Bourdieu, P. (1997). Televizyon Üzerine. Turhan Ilgaz (Çev.), İstanbul: YKY.

Çınar, A. (2013). Modernizm, Kent ve Toplum. Bursa: Emin.

Çoban, B. (2006). Louis Althusser. Batuş, G., Alver, F. vd (ed.) Kadife Karanlık II Ayna Şövalyeleri içindeİstanbul: $\mathrm{Su}$.

Demir, R. (2019), Bir Kent Distopyası Olarak Tahsin Yücel'in Gökdelen’i ve Romanın Distopya Edebiyatı İçindeki Yeri, Çukurova Üniversitesi Türkoloji Araştırmaları Dergisi (ÇÜTAD), 4 (2), s. 446-467.

Dorso,F.(2019).İstanbul'un Kalbinde Belirsiz Bir Mekân, 2001'de II. Theodosius Surları)http://webcache.googleusercontent.com/search?q=cache:6snuvd5HyoEJ:books.opened ition.org/ifeagd $/ \mathrm{pdf} / 2870+\& \mathrm{~cd}=2 \& \mathrm{hl}=\mathrm{tr} \& \mathrm{ct}=\mathrm{clnk} \& \mathrm{gl}=\operatorname{tr} \& \mathrm{client}=$ safari

Habermas, J. (2014). Kamusallığın Yapısal Dönüşümü, 12. Baskı, Çev: Tanıl Bora, Mithat Sancar. İstanbul: İletişim.

Harvey, D. (2013). Sosyal Adalet ve Şehir, 4. Baskı, Çev: Mehmet Moralı. İstanbul: Metis.

Hazar, E. (2012). İstanbul'u Baştan Yaratanlar, Niyorklu Temel ile Oflu Trump.http://www.eskop.com/skopbulten/istanbulu-bastan-yaratanlar-niyorklu-temel-ile-oflu-trump/479 
Following the paths of the new life architectures in cinema and commercials in the context of Tahsin Yücel's Gökdelen / R. Köse Özelçi (pp. 279-296)

İnceoğlu, Y. (2006) Medya, İktidar İlişkilerinin Tarihsel Gelişimi. http://bianet.org/bianet/medya/86980-medya-iktidar-iliskilerinin-tarihsel-gelisimi

Karaca Küçük, Ş. (2015). Distopik bir Roman Olarak Gökdelen'de Yapı ve izlek. Turkish Studies International Periodical For the Languages, Literature and History of Turkish or Turkic Volume 10/8 Spring

Karyelioğlu, S. (2015). Türkiye'de İnşaat Sektörünün Gelişimi Bağlamında Trabzon’da Müteahhitliğin Sosyo-Kültürel Temelleri. Karadeniz İncelemeleri Dergisi. (19) s.207-240.

Kıran, A., Kıran, Z. (2011). Yazınsal Okuma Süreçleri. Ankara: Seçkin.

Orwell, G. (2003). 1984, Çev: Ege Acar. İzmir: İlya.

Püsküllüoğlu, A. (2002). Türkçe Sözlük, Türkiye Türkçesinin En Büyük Sözlüğü. Ankara: Doğan Kitap.

Sağlam, S. (2018). “Üniversite Öğrencilerinin Çok katlı bina ve Gökdelenler Hakkındaki Düşünceleri”, Üçüncü Sektör Sosyal Ekonomi, 2018, 53 (3), s.1323-1336, doi. 10.15659/3-sektorekonomi.18.12.1053.

Sargon, E. Babil, Eski Mezopotamya'nın en büyük ve en ünlü şehri, https://islamansiklopedisi.org.tr/babil (erişim tarihi: 17.03.2020)

Solak, C. (2012). Bir Ekoeleştiri Denemesi: Behiç Ak’ın Tek Kişilik Şehir Oyununda Birey, Toplum ve Çevre İlişikleri, A.Ü. Türkiyat Araştırmaları Enstitüsü Dergisi (TAED), 47. Erzurum, s.211-224.

Stam, R. Vd. (2019). Sinemasal Göstergebilim Sözlüğü. Çev: Simten Gündeş. İstanbul: Es.

Şimşek, Sedat (2009). Medya-Siyaset- İktidar Üçgeninde Medya Gerçeği, Selçuk Üniversitesi İletişim Fakültesi Akademik Dergisi, Cilt 6, Sayl 1.s.124-143.

Tecimer, Ö. (2005). Sinema: Modern Mitoloji. İstanbul: Plan b.

Tümtaş, M. S. (2012). Kent, Mekân ve Ayrışma Dinamikleri. Ankara: Detay.

Türk, B.H. (2016). Şantiyeler Kralı: Bir Yeniz Zaman Muktediri Olarak Ali Ağaoğlu. Tanıl Bora (Ed.), İnşaat Ya Resulullah içinde. İstanbul: Birikim Kitapları.

Uşaklıgil, E. (2014). Bir Şehri Yoketmek, İstanbul'da Kazanmak ya da Kaybetmek. İstanbul: Can Yay.

Yücel, T. (2012). Gökdelen.6. Baskı. İstanbul: Can.

Wacquant, L. (2015). Kent Paryaları, İleri Marjinalliğin Karşılaştırmalı Sosyolojisi. 2. Baskı. Çev: Mehmet Doğan. İstanbul: Boğaziçi Üniversitesi Yay.

http://www.takvim.com.tr/Ekonomi/2011/07/28/sen-trumpi-bile-gectin

http://www.maslak1453.com/genel-tanitim/o/1/agaoglu-maslak-1453-istanbul.html

http://www.agaoglu.com.tr/tr/newsDetails/2016-satis-rekortmeni-maslak-1453-oldu

http://aktuelarkeoloji.com.tr/istanbulun-surlari-can-cekisiyor erişim tarihi: 08.02.2020)

https://www.youtube.com/watch?v=sBkZRMljsgo (Maslak 1453 reklam filmi; "Yeni İstanbul Fatihi Ali A ğaoğlu- $\quad \mathrm{Bu}$ değil!, $\quad$ erişim tarihi:11.02.2020); https://www.youtube.com/watch?v=pr3E9PNBY4c (Ağaoğlu my home Maslak, erişim tarihi:11.02.2020);

https://www.youtube.com/watch?v=_yNT40Gyi5M (Ağaoğlu my World Europe), erişim tarihi:11.02.2020)

https://www.youtube.com/watch?v=XBjHzml5INU (Ağaoğlu My World, erişim tarihi:11.02.2020)

https://www.youtube.com/wath?v=GsLZH9x_DuY (Ağaoğlu Türkiye'ye Sesleniyor reklamı, erişim tarihi:11.02.2020)

Begeç,H.,Hamidabad,B.D.(2015)

https://www.researchgate.net/profile/Darioush_Bashiri_Hamidabad/publication/275643176_ 
GOKDELENLER_ICIN_SINIR_VAR_MIDIR_IS_THERE_A_LIMIT_FOR_THE_SKYSCRAP ERS/links/554168070cf2b790436bcc9f.pdf (erişim tarihi: 17.03.2020)

http://tiyatronline.com/-tek-kisilik-sehir_-ankara-devlet-tiyatrosu-3588 